\title{
Heavy Metals Uptake by Wheat, Bean and Onion and Characterization of Microorganisms in a Long-Term Sewage Wastewater Treated Soil
}

\author{
A. Elgharably* and H.M. Mohamed \\ Department of Soils and Water, Faculty of Agriculture, Assiut \\ University, Assiut 71526, Egypt.
}

\begin{abstract}
7 HE STUDY evaluated wheat, faba bean and onion uptake of Fe, $\mathrm{Mn}, \mathrm{Zn}, \mathrm{Cu}, \mathrm{Cd}$ and $\mathrm{Pb}$ and characterized the microbial biomass and distribution in a soil under irrigation with sewage wastewater for 40 years at ElMadabegh, Assiut, Egypt.
\end{abstract}

With sewage wastewater irrigation concentrations of $\mathrm{Fe}, \mathrm{Mn}, \mathrm{Zn}$ and $\mathrm{Cu}$ in all crops are optimal for plant growth, but that of $\mathrm{Cd}$ and $\mathrm{Pb}$ were high. Compared to that irrigated with the Nile River fresh water, irrigation with sewage waste water resulted in lower dehydrogenase activity, soil respiration and microbial biomass carbon and higher quantities of bacteria, actinomycetes, fungi and denitryfing bacteria and decreased the quantities of nitrifying bacteria, Azotobacter bacteria and sulphere oxidizing bacteria.

In the rhizosphere of onion, the biomass of actinomycetes and fungi was lower, but that of bacteria was higher with sewage wastewater irrigation than with the Nile River fresh water irrigation. Lowest log numbers of fungi, denitryfing bacteria, nitrifying bacteria and Azotobacter bacteria were found in the rhizosphere of onion, but the log numbers of certain other bacteria and actinomycetes were not significantly different between the three crops.

These results showed high $\mathrm{Pb}$ and $\mathrm{Cd}$ concentrations in the crops irrigated with the sewage wastewater and that the sewage wastewater affected the quantity of common and functional microorganisms in the plant rhizosphere, but the magnitude of the microbial population is dependent on the crop type.

Keywords: Functional microorganisms, Heavy metals, Microbial biomass carbon, Sewage wastewater, Soil respiration.

The use of sewage effluents for irrigating agricultural land is a worldwide practice (Feign et al., 1991 and Yadav et al., 2002). It is especially common in developing countries, where water treatments of swage wastewater cost is high (Rattan et al., 2005 and Masto et al., 2009). The rapid development of agricultural and tourist activities, fast industrialization and urbanization, and poor water management practices have made freshwater availability a limiting factor in Egypt. As there is a gradual decline in availability of fresh water for

E-mail of the corresponding author: ahmed.elgharably@aun.edu.eg 
irrigation in Egypt, the use of sewage and other industrial effluents for irrigating agricultural lands is on the rise (Feng et al., 2003 and Liu et al., 2005).

Soil microorganism is one of the most active factors in soils. The quantity and composition of microorganisms, especially those surrounding the crop roots, are closely related to the growth of crops (Kandeler et al., 1996). These microorganisms can directly transform the organic substances surrounding the roots into inorganic materials that can be absorbed by the crops (Fliessbach et al., 1994). In addition, they can produce growth-stimulating hormones and antibiotics, thus inhibiting the growth of pathogenic microorganisms and stimulating the crop growth (Sharma, 2006).

Plant species have a variety of capacities in removing and accumulating heavy metals, so there are reports indicating that some species may accumulate specific heavy metals, causing a serious health risk to human health when plants based food stuff are consumed (Smith et al., 1996 and Okoronkwo \& Onwuchekwa, 2005). This concern is of special importance where untreated sewage is applied for long periods to grow vegetables in urban lands.

In Assiut City, municipal wastewater from different sources is collected at ElMadabeghh village, which lies $8 \mathrm{~km}$ northwest of Assiut City. Several cereal and vegetable crops are being grown by the farmers in ElMadabeghh village over decades. Farmers irrigate the agricultural soils using either sewage water, or the Nile River fresh water and sometimes mix either type with water from Ibrahimia canal.

The quality of soils has been deteriorated due to pollution with the heavy metals of the sewage water (Elgharably et al., 2014). Changes in soil biological characteristics may be sensible indicators of soil quality, since they are more dynamic and often more sensitive than physical or chemical soil properties. The effects of the addition of sewage sludge to soils on soil microorganisms have been studied in detail (Chander and Brookes, 1991 and Fliessbach et al., 1994 and Kandeler et al., 1996), but less information is available on the effects of sewage effluent irrigation on soil processes such as denitrification, microbial respiration, and enzyme activities (Saber, 1986 and Goyal et al., 1995 and Valsecchi et al., 1995).

The present study was conducted to examine the effect of sewage irrigation on the quantity and distribution of soil common microorganisms including bacteria, actinomycetes and fungi and functional microorganisms including nitrifying bacteria (NB), denitrifying bacteria (DB), Azotobacter (AB) and sulphere oxidizing bacteria (SOB). The quality status, in terms of heavy metals content, of several vegetable and cereal crops was also evaluated in this study.

\section{Materials and Methods}

Soil

Soil samples were collected from five sites, labelled SW1, SW2, SW3, SW4 and SW5, in ElMadabegh, Assiut, Egypt, where the soils have been irrigated Egypt. J. Soil Sci. 56, No. 4 (2016) 
with either the Nile River fresh water (FW) or the sewage wastewater (SW) for more than 40 years. Rotationally, soil of SW2 was under maize followed by wheat whereas that of the other sites was under faba bean-onion-wheat cultivation At each site, three plots with area size of more than $200 \mathrm{~m}^{2}$ area have been allocated for sampling. The samples were collected from the Nile River irrigated soils for use as a reference to assess the impact of irrigation with sewage wastewater on the quantity and distribution of soil common and functional microorganisms. The sample was taken from the soil surrounding plant roots in the subsurface layer $(5-20 \mathrm{~cm})$ after removing the top $5 \mathrm{~cm}$ of the soil surface. The soil samples $(1 \mathrm{~kg})$ were mixed and placed in sterile plastic bags and transported to the laboratory for preservation in refrigerator $\left(4^{\circ} \mathrm{C}\right)$ and then determination of quantity and distribution of soil common and functional microorganisms. Chemical and physical characteristics of the collected soil samples are presented in the study conducted by Elgharably and Allam (2014).

\section{Dilution of soil samples}

An aliquot of $10 \mathrm{~g}$ (fresh weight) of the mixed material from each soil was suspended in $90 \mathrm{ml}$ sterile $0.9 \%$ sodium-chloride solution. The soil suspensions were shaken for $30 \mathrm{~min}$ on a rotary shaker $(150 \mathrm{rpm})$ at room temperature $\left(30^{\circ} \mathrm{C}\right)$ for desorption of bacterial cells. The soil suspension was allowed to settle for $1 \mathrm{~min}$, before the supernatant containing the desorbed bacterial cells was decanted into $250 \mathrm{ml}$ sterile Erlenmeyer flasks. From the supernatant a series of $10^{-1}$ dilutions (highest dilution step: $10^{-10}$ ) was prepared. These processes were carried out in sterile conditions to avoid contamination.

\section{Determination of the quantity of common soil microorganisms}

The quantity of common soil microorganisms including bacteria, actinomycetes and fungi was determined by the plate counting method. The series of soil diluents with $1 \mathrm{ml}$ was taken for inoculation into the tube liquid medium. The dilution of soil for bacteria and actinomycetes was from $10^{-5}$ to $10^{-7}$ whereas that of fungi was from $10^{-3}$ to $10^{-5}$. Three replicates were performed in each dilution, and a blank was set to test whether, or not, the medium had been contaminated. Cultures were prepared for Bacteria, in beef extract peptone medium at $37^{\circ} \mathrm{C}$ for 3 days, actinomycetes, in starch casein medium at $37^{\circ} \mathrm{C}$ for 3 days, and fungi, in Martin's medium (100 ml culture with one drop of lactic acid) at $25^{\circ} \mathrm{C}$ for 5 days. After ending up the incubation, the proper dilution was selected and the average colony count was performed. The value was calculated by the following formula:

$\mathrm{C}=\mathrm{ND} / \mathrm{W}$, where, $\mathrm{C}\left(\mathrm{cfu} \mathrm{g}^{-1}\right)$ is the colony count per gram dry soil, $\mathrm{N}$ (cfu) is the average colony count in the same dilution, $\mathrm{D}$ is the dilution multiple with all colony appeared, and $\mathrm{W}(\mathrm{g})$ is the quality of dry soil (Harrigan and Mc Cance, 1966). 


\section{Determination of quantity of soil functional microorganisms}

The quantity of functional microorganisms including nitrite oxidizing bacteria (NOB), nitrifying bacteria (NB), denitrifying bacteria (DB), Azotobacter (AB) and sulphere oxidizing bacteria (SOB) was determined using the most probable number (MPN) method (Yang, 2002). The series of soil diluents with 1 $\mathrm{ml}$ was taken for inoculation into the tube liquid medium. Five replicates were performed in each dilution, and a blank was set to test whether, or not, the medium had been contaminated. The dilution $\left(10^{-2}\right.$ to $\left.10^{-7}\right)$ of soil for NOB and NB was cultured in Stephenson media A and B, respectively at $28^{\circ} \mathrm{C}$ for 14 days. The dilution $\left(10^{-4}\right.$ to $\left.10^{-8}\right)$ of soil for $\mathrm{DB}$ was cultured in Giltay medium at $30^{\circ} \mathrm{C}$ for 14 days. The dilution $\left(10^{-2}\right.$ to $\left.10^{-6}\right)$ of soil for $\mathrm{AB}$ was cultured in the modified Ashby's medium without nitrogen at $28^{\circ} \mathrm{C}$ for 7 or 14 days. The dilution $\left(10^{-1}\right.$ to $\left.10^{-5}\right)$ of soil for CDB was cultured in Hirsch Johnson's medium at $28^{\circ} \mathrm{C}$ for 14 days (Li et al., 1996). After incubation, the microbial growth index was considered after appearance of the characteristic reaction in the last concentrated dilution. The approximation of most probable number was calculated following Harrigan and Mc Cance, 1966) using the formula: $\mathrm{C}=$ $\mathrm{MD} / \mathrm{W}$, where $\mathrm{C}\left(\mathrm{cfu} \mathrm{g}^{-1}\right)$ is the colony count per gram dry soil, $\mathrm{M}$ is the approximation of most probable number, $\mathrm{D}$ is the highest dilution multiple with all colony appeared and $\mathrm{W}(\mathrm{g})$ is the quality of dry.

\section{Determination of soil biological parameters}

Microbial biomass carbon (MBC) was measured following the fumigation extraction method (Jenkinson and Ladd, 1981). Soil dehydrogenase was determined using the method of Klein et al. (1971). Soil respiration of $\mathrm{CO}_{2}$ was measured using a constant volume Warburg manometer (Umbrert et al., 1972).

\section{Plants}

Shoots were collected randomly at the harvest time from the growing crops, faba bean, wheat and onion at the sites where the soil samples were collected. The samples were washed thoroughly with tap water followed by distilled water to remove adsorbed elements. Samples were cut to small pieces, air dried for 2 days and kept in hot air oven at $70{ }^{\circ} \mathrm{C}$ for $4 \mathrm{hr}$. Dried samples were ground and then acid-digested $\left(2: 1 \mathrm{HNO}_{3}: \mathrm{HClO}_{4}\right.$ acid mixture). Digested solution was cooled, filtered and made up to $100 \mathrm{ml}$ with distilled water and stored in glass bottles for analysis. The concentration of $\mathrm{Fe}, \mathrm{Mn}, \mathrm{Zn}, \mathrm{Cu}, \mathrm{Cd}$ and $\mathrm{Pb}$ in the digests solutions was measured using the atomic absorption spectrophotometer (GBC300).

\section{Statistical analysis}

Data reported in this paper were the mean values based on the three replicates. Differences among treatments were tested by ANOVA. The mean values among treatments were compared using Duncan's Multiple Range test at $P=0.05$. Statistical analysis of the data was performed using the statistical computer program Statsoft, series of 1995.

Egypt. J. Soil Sci. 56, No. 4 (2016) 


\section{Results and Discussion}

Effect of sewage wastewater on shoot metal content of wheat, faba bean and onion

Average concentrations of $\mathrm{Fe}, \mathrm{Mn}, \mathrm{Zn}, \mathrm{Cu}, \mathrm{Cd}$ and $\mathrm{Pb}$ in the shoot dry matter (DM) of wheat, faba bean and onion are presented in Table 1.

The concentration of $\mathrm{Fe}, \mathrm{Mn}, \mathrm{Zn}$ and $\mathrm{Cu}$ seems optimal for the tested crops. Concentrations of heavy metals varied between the field crops, but not between the sampled sites for each crop. Therefore the average shoot concentration of each element for the five sites is presented in Table 1.

TABLE 1. Average concentration ( $\mathrm{mg} \mathrm{kg}^{-1}$ dry matter) of metals in the shoot of wheat, faba bean and onion at 5 sites in EIMadabeghh Village, Assiut, irrigated with either sewage wastewater (SW) or the Nile River fresh water (FW)

\begin{tabular}{|c|c|c|c|c|c|c|c|}
\hline \multirow{2}{*}{ Crop } & \multirow{2}{*}{$\begin{array}{c}\text { Irrigation } \\
\text { type }\end{array}$} & $\mathbf{F e}$ & Zn & Mn & $\mathbf{C u}$ & Cd & $\mathbf{P b}$ \\
\hline & & \multicolumn{6}{|c|}{$\mathrm{mg} \mathrm{kg}^{-1}$ dry matter } \\
\hline \multirow{2}{*}{ Wheat } & FW & $\begin{array}{c}200.0 \pm \\
9.5\end{array}$ & $\begin{array}{c}22.0 \pm \\
3.2\end{array}$ & $\begin{array}{c}30.0 \pm \\
4.1\end{array}$ & $\begin{array}{c}2.0 \pm \\
1.2\end{array}$ & 0 & $\begin{array}{c}0.2 \pm \\
0.5\end{array}$ \\
\hline & SW & $\begin{array}{c}231.3 \pm \\
15.1\end{array}$ & $\begin{array}{c}40.0 \pm \\
5.1\end{array}$ & $\begin{array}{c}54.5 \pm \\
2.3\end{array}$ & $\begin{array}{c}10.0 \pm \\
2.1\end{array}$ & $\begin{array}{c}8.0 \pm \\
1.0\end{array}$ & $\begin{array}{c}18.1 \pm \\
0.2\end{array}$ \\
\hline \multirow{2}{*}{ Bean } & FW & $\begin{array}{c}206.0 \pm \\
12.1\end{array}$ & $\begin{array}{c}55.7 \pm \\
4.2\end{array}$ & $\begin{array}{c}54.0 \pm \\
3.4\end{array}$ & $\begin{array}{c}9.2 \pm \\
0.8\end{array}$ & 0 & $\begin{array}{c}0.1 \pm \\
0.0\end{array}$ \\
\hline & SW & $\begin{array}{c}282.1 \pm \\
15.1\end{array}$ & $\begin{array}{c}65.0 \pm \\
4.1\end{array}$ & $\begin{array}{c}76.2 \pm \\
5.1\end{array}$ & $\begin{array}{c}15.5 \pm \\
1.1\end{array}$ & $\begin{array}{c}3.4 \pm \\
0.8\end{array}$ & $\begin{array}{c}12.55 \pm \\
1.2\end{array}$ \\
\hline \multirow{2}{*}{ Onion } & FW & $\begin{array}{c}170.0 \pm \\
2.5\end{array}$ & $\begin{array}{c}29.0 \pm \\
4.3\end{array}$ & $\begin{array}{c}22.0 \pm \\
4.1\end{array}$ & $\begin{array}{c}9.8 \pm \\
2.1\end{array}$ & 0 & $\begin{array}{c}2.0 \pm \\
0.5\end{array}$ \\
\hline & SW & $\begin{array}{c}201.5 \pm \\
14.1\end{array}$ & $\begin{array}{c}38.3 \pm \\
4.1\end{array}$ & $\begin{array}{c}52.8 \pm \\
2.6\end{array}$ & $\begin{array}{c}16.0 \pm \\
3.2\end{array}$ & $\begin{array}{c}6.4 \pm \\
1.2\end{array}$ & $\begin{array}{c}14.7 \pm \\
0.7\end{array}$ \\
\hline
\end{tabular}

In the SW irrigated soils, among the studied crops faba bean seems containing the highest concentrations of all measured metals and no significant difference was found between wheat and onion.

The variation in the heavy metal concentrations between the collected field crops reflects the differences in uptake capabilities and their further translocation to the edible portion of the plants. Since these crops grew under the same soil and irrigation conditions, the variations in heavy metal concentrations between the crops under investigation at the same site may be ascribed to the differences in their morphology and physiology for heavy metal uptake, exclusion, accumulation and retention (Kumar et al., 1995).

Egypt. J. Soil Sci. 56, No.4 (2016) 
The plants grown on the soil irrigated with SW contained higher concentrations of heavy metals than that grown in soils irrigated with the fresh water. The use of sewage wastewater in crop irrigation at the all locations increased the uptake and accumulations of heavy metals in the plants. The concentrations observed in this study were higher than those reported by other workers (Adhikari et al., 2004 and Kawatra \& Bakhetia, 2008).

Concentrations of $\mathrm{Fe}, \mathrm{Mn}, \mathrm{Zn}$ and $\mathrm{Cu}$ in the studied crops are within the acceptable limits for plant growth as well as consumption by humans and animals. Data obtained reveal that in the SW-irrigated soils, all crops contained concentrations of $\mathrm{Pb}$ and $\mathrm{Cd}$ above the permissible levels for consumption by humans, or animals (Abdala and Chmtelnicka, 1990). Lead is a toxic element that can be harmful to plants, although plants usually show ability to accumulate large amounts of $\mathrm{Pb}$ without visible changes in their appearance or yield. In many plants, $\mathrm{Pb}$ accumulation can exceed several hundred times the threshold of maximum level permissible for human (Wierzhicka, 1995). The introduction of $\mathrm{Pb}$ into the food chain may affect human health and thus, studies concerning $\mathrm{Pb}$ accumulation in vegetables have increasing importance (Coutate, 1992). The maximum $\mathrm{Pb}$ limit for human and animal health has been established for edible parts of crops in china as $0.2 \mathrm{mg} \mathrm{kg}^{-1}$ plant, and by WHO as $0.3 \mathrm{mg} \mathrm{kg}^{-1}$ plant (Codex, 2001). In this study, $\mathrm{Pb}$ concentration in the shoots was found in the range $12.5-18.1 \mathrm{mg} \mathrm{kg}^{-1}$ dry matter in the $\mathrm{SW}$ treated soils, which establishes a critical threat for consumers.

The high $\mathrm{Pb}$ concentration in the vegetables treated with UW could result from contamination of the the Nile River fresh water with $\mathrm{Pb}$ and other elements due to the run-off of sewage water in this area over 45-50 years, or use of sewage effluents as fertilizers (confirmed by most farmers). On the whole, all crops investigated in this study are contaminated with $\mathrm{Pb}$.

Data also indicate that $\mathrm{Cd}$ concentration is present at high concentration in the shoots of wheat and onion compared to faba bean. WHO standards for Cd in vegetables stated $0.1 \mathrm{mg} \mathrm{kg}$ dry matter as the maximum allowable concentration in foods (Codex, 2001).

Data of Fazeli (1998) and Shariati \& Farshi (1997) is in line with the results of this study. The concentration of $\mathrm{Cd}$ in the studied crops grown on soils irrigated with sewage water was several times the permissible levels allowed by WHO. No Cd was found in the plants grown in soils treated with UW which may result from chemical interactions in the rhizosphere, or in the root cortex.

Effect of sewage wastewater on soil common and functional microorganisms

Different common microorganisms in the plant rhizosphere vary differently in the response to the water quality. 
De-Lan et al. (2012) found that compared to the fresh water, irrigation with sewage wastewater increased the quantity of bacteria by $50.39 \%$ and decreased the quantity of actinomycetes and fungi by $39.78 \%$ and $79.55 \%$, respectively. Yuan et al. (2003) found that compared to fresh water irrigation with sewage wastewater had no significant effect on the biomass of bacteria, actinomycetes and fungi. Compared to the soil irrigated with Nile water, in sewage irrigated soils, the quantity of bacteria, actinomycetes and fungi was increased by approximately 20, 12 and 13\%, respectively (Table 2) with no, or slight differences between sites. Data of this study is in match with the data of (Zhang and Wang, 2009).

TABLE 2. Quantity (log number $\mathrm{g}^{-1}$ soil) of bacteria (BA), actinomycetes (ACT) and fungi $(\mathrm{Fi})$, nitrite oxidizing bacteria (NOB), nitrate bacteria (NB), denitrifying bacteria (DB), Azotobacter (AB), sulphate oxidizing bacteria (SOB) in soils at 5 sites (SW1-SW5) irrigated with sewage wastewater and at a site irrigated with the Nile river water (Ref.)

\begin{tabular}{cccccccc}
\hline \multirow{2}{*}{ Soil site } & BA & ACT & FI & NB & DB & AB & SOB \\
\cline { 2 - 7 } & \multicolumn{7}{c}{$\log$ number $\left(\mathbf{g}^{-1}\right.$ soil; dry weight basis) } \\
\hline SW1 & $6.52^{\mathrm{a}}$ & $4.43^{\mathrm{a}}$ & $2.53^{\mathrm{d}}$ & $4.21^{\mathrm{b}}$ & $4.84^{\mathrm{a}}$ & $3.43^{\mathrm{bc}}$ & $3.26^{\mathrm{e}}$ \\
\hline SW2 & $6.39^{\mathrm{b}}$ & $4.41^{\mathrm{a}}$ & $2.58^{\mathrm{d}}$ & $4.25^{\mathrm{b}}$ & $4.81^{\mathrm{a}}$ & $3.47^{\mathrm{bc}}$ & $3.35^{\mathrm{d}}$ \\
\hline SW3 & $6.38^{\mathrm{b}}$ & $4.47^{\mathrm{a}}$ & $2.56^{\mathrm{d}}$ & $4.11^{\mathrm{d}}$ & $4.78^{\mathrm{a}}$ & $3.51^{\mathrm{c}}$ & $3.47^{\mathrm{c}}$ \\
\hline SW4 & $6.32^{\mathrm{b}}$ & $4.27^{\mathrm{b}}$ & $2.43^{\mathrm{c}}$ & $4.31^{\mathrm{c}}$ & $4.77^{\mathrm{a}}$ & $3.70^{\mathrm{d}}$ & $3.52^{\mathrm{c}}$ \\
\hline SW5 & $6.23^{\mathrm{c}}$ & $4.18^{\mathrm{c}}$ & $2.31^{\mathrm{b}}$ & $4.23^{\mathrm{b}}$ & $4.62^{\mathrm{b}}$ & $3.41^{\mathrm{b}}$ & $3.61^{\mathrm{b}}$ \\
\hline Ref. & $5.09^{\mathrm{d}}$ & $3.85^{\mathrm{d}}$ & $2.15^{\mathrm{a}}$ & $4.78^{\mathrm{a}}$ & $4.15^{\mathrm{c}}$ & $3.94^{\mathrm{a}}$ & $4.78^{\mathrm{a}}$ \\
\hline
\end{tabular}

In the soils irrigated with sewage wastewater the quantity of $\mathrm{NB}, \mathrm{AB}$ and SOB was lower than that measured in the soil irrigated with Nile Water by approximately 12,10 and $29 \%$, respectively, with no, or slight differences between sites. The quantity of DB was $6-16 \%$ higher in the sewage wastewater irrigated soils than that counted in the control soil.

Along with the concentration of beer wastewater increasing continuously, the quantities of aerobic cellulose decomposing bacteria, nitric acid bacteria, nitrous acid bacteria and free-living nitrogen fixing bacteria, all presented the law of first increasing and then decreasing (Shang et al., 2007). Population of nitrogen fixing bacteria was decreased with long-term organic sewage irrigation then replaced with fresh water irrigation and the populations were gradually increased. Because of the effects of long-term organic sewage irrigation, it could not make nitrogen-fixing bacteria populations recover fully, even for 30 years or longer (Zhang et al., 2007).

The frequent application of sewage wastewater, with the possible changes in the pollutants concentration and in the microbial composition of the sewage wastewater, might have significantly affected the soil microbial community structure. Long-term sewage irrigation would lead to great decrease of soil 
microbial biomass and population, recession of community structure and decline of diversity, and then cause disorder of soil structure and function and disruption of ecological balance.

Effect of sewage wastewater on the quantity of common microorganisms in the soil rhizosphere of different crops

With irrigation using the oily sewage in the paddy soil of Shenfu area of China, the amounts of aerobic heterotrophic bacteria and fungi in rice rhizosphere strongly increased, but that of the actinomycetes slightly increased ( $\mathrm{Li}$ et al., 2005). In comparison with tap-water irrigation, the numbers of bacteria, actinomyces and fungi were lower in Kentucky bluegrass soil after irrigation with tertiary effluent for years, but higher in Tall Fescue soil (Han et al., 2006).

Data presented in Fig. 1 showed that, compared to the irrigation with fresh water, irrigation of faba bean with the sewage wastewater resulted in a higher quantity of bacteria, but had no effect on the quantity of fungi and actinomycetes. In the rhizosphere of onion, with sewage wastewater the quantity of actinomycetes and fungi was lower while the quantity of bacteria was significantly $(p<0.05)$ higher. In the sewage wastewater irrigated soil, the quantity of all studied common microorganisms in the faba bean rhizosphere has an increasing trend, but in the wheat rhizosphere it has a declining trend.

Effect of the sewage wastewater on the quantity of soil functional microorganisms in the rhizosphere of faba bean, onion and wheat

Ge et al. (2009) found that the numbers of bacteria, actinomycete, cellulose decomposing bacteria, Azotobacter, nitrobacteria and ammonifying bacteria were decreased, but fungi and denitro bacteria increased after the long-term irrigation with sewage wastewater. Compared with the fresh water irrigation, nitrogenfixing bacteria and nitrifying bacteria numbers in rhizosphere soils of rape and cotton had no significant change (Yuan et al., 2003).

In this study, Fig. 2 shows the effect of irrigation with fresh water, or sewage wastewater on the functional microorganisms.

In the rhizosphere of faba bean, the quantity of NB and DB was significantly lower $(p<0.05)$ while that of AB and SOB was higher $(\mathrm{P}<0.05)$ with irrigation with sewage wastewater than with fresh water (Fig. 2). There was a significant decrease in the quantity of NB in the rhizosphere with sewage wastewater irrigation while the quantity of DB remained almost the same under fresh water and wastewater irrigation. The quantity of $\mathrm{AB}$ and SOB was extremely higher with sewage wastewater irrigation compared to the control.

Compared to the fresh water irrigation, the quantity of DB and SOB in the rhizosphere soils of wheat was significantly higher but that of $A B$ was significantly lower with sewage wastewater irrigation while that of NB remained the same.

Egypt. J. Soil Sci. 56, No. 4 (2016) 

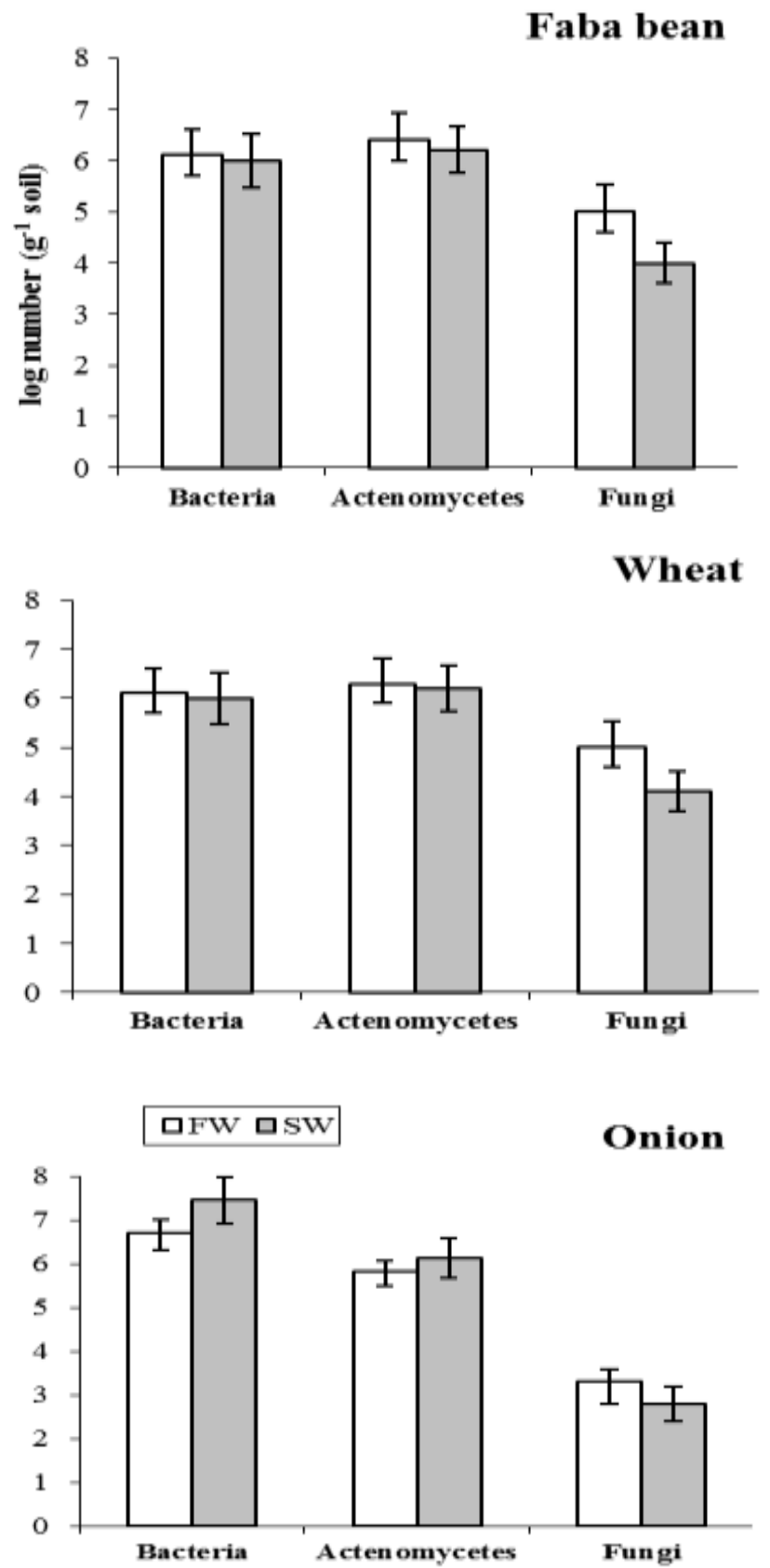

Fig. 1. Effect of irrigation with sewage wastewater (SW) and Nile River fresh water (FW) on the quantity (log number $\mathrm{g}^{-1}$ soil) of bacteria, actinomycetes and fungi in the soil rhizosphere of faba bean, onion and wheat 


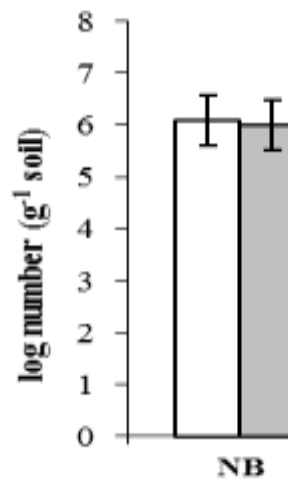

Faba bean
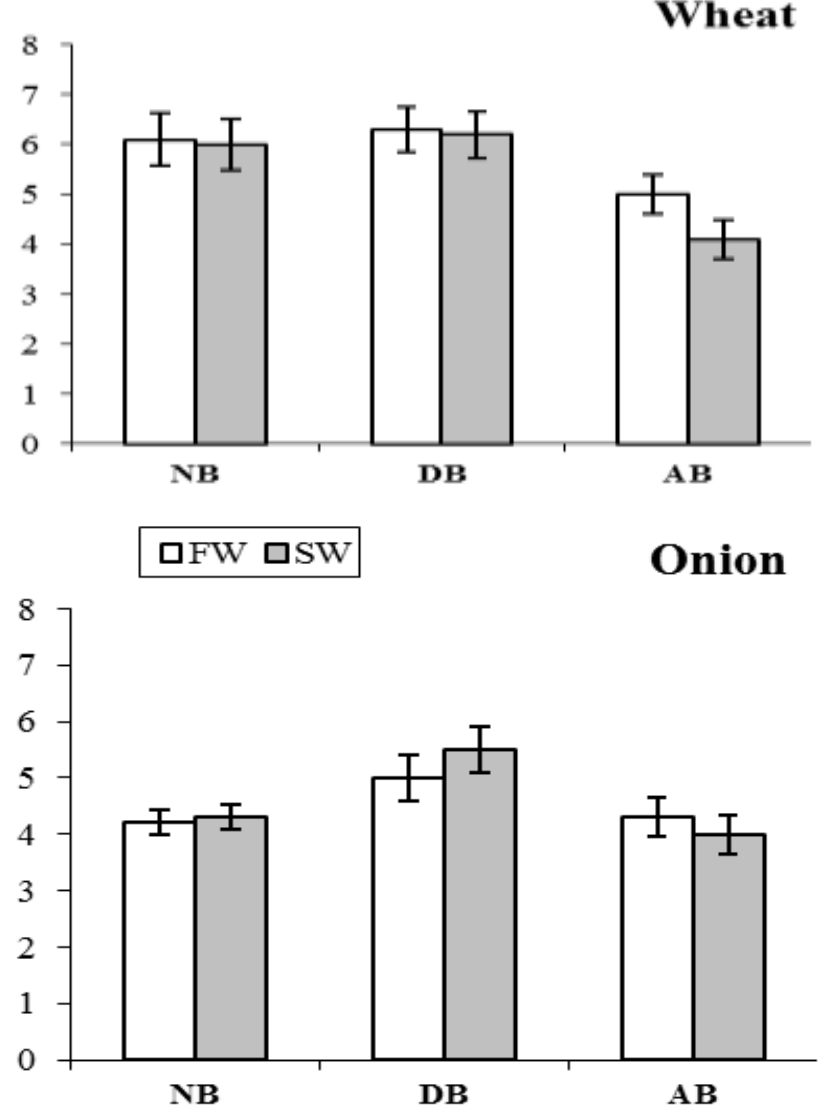

Fig. 2. Effect of irrigation with sewage wastewater (SW) and Nile River fresh water (FW) on the quantity (log number $\mathrm{g}^{-1}$ soil) of nitrate bacteria (NB), denitrifying bacteria (DB) and Azotobacter (AB) in the soil rhizosphere of faba bean, onion and wheat

Egypt. J. Soil Sci. 56, No. 4 (2016) 
These results suggest that irrigation with sewage wastewater has a large effect on the quantity of functional microorganisms in the soil rhizosphere soils of different crops. The quantity of $\mathrm{AB}$ and SOB is significantly different between the sewage irrigation group and the control group, indicating that sewage irrigation largely affects the quantity of $\mathrm{AB}$ and SOB. In addition, SOB quantity has an increasing trend in the sewage irrigation group, indicating that sewage irrigation is favorable for the proliferation of SOB.

\section{Soil microbial parameters}

Changes in the soil biological parameters may be sensible indicators of soil health, since they are more dynamic and often more sensitive than physical or chemical soil properties. Data presented in Tables 2 and 3 show the effects of irrigation with the fresh water, or with the sewage wastewater on the dehydrogenase activity, the soil respiration and the microbial biomass carbon.

Compared to the fresh water, irrigation with sewage wastewater significantly decreased the dehydrogenase activity, the soil respiration and the microbial biomass carbon; the dehydrogenase activity ranged from $51.00 \mu \mathrm{g} \mathrm{TPF} \mathrm{g}^{-1} 24 \mathrm{~h}$ for Sw-5 to 113.00 for SW-1 (Table 3). Dehydrogenase activity is generally sensitive to heavy metal pollution (Kandeler et al., 1996). Masto et al. (2009) reported that soil respiration, microbial biomass and other enzyme activities were lower in the sewage wastewater irrigated soil than in the rain-fed soil. Application of wastewater containing organic matter and nutrient has been found to increase total soil microbial biomass (Goyal et al., 1995). In this study, soil respiration was much affected by the sewage wastewater treatment; the least respiration was recorded under SW-1 $\left(3.88 \mu \mathrm{O}_{2} \mathrm{~g}^{-1} \mathrm{~h}^{-1}\right)$, whereas the respiration recorded with fresh water irrigation was 10.86 . The microbial biomass carbon was significantly affected by the sewage wastewater treatment; highest MBC (592 $\mathrm{mg} \mathrm{kg}^{-1}$ ) was found in SW-5 and lowest MBC (390 $\left.\mathrm{mg} \mathrm{kg}^{-1}\right)$ in SW-1.

TABLE 3. Soil respiration ( $\left.\mu \mathrm{l} \mathrm{CO} \mathrm{C}^{-1} \mathrm{~h}^{-1}\right)$, microbial biomass $\mathrm{C}\left(\mathrm{MBC} ; \mathrm{mg} \mathrm{kg}^{-1}\right)$ and Dehydrogenase ( $\mu \mathrm{g}$ TPF $\mathrm{g}^{-1}$ for $24 \mathrm{~h}$ ) in soils at 5 sites (SW1-SW5) irrigated with sewage wastewater and at a site irrigated with the Nile river water (Ref.)

\begin{tabular}{|c|c|c|c|}
\hline \multirow{2}{*}{ Soil site } & Respiration & MBC & Dehydrogenase \\
\hline & $\left(\mu \mathrm{l} \mathrm{CO} \mathrm{O}^{-1} \mathbf{h}^{-1}\right)$ & $\left(\mathrm{mg} \mathrm{kg}^{-1}\right)$ & $\left(\mu \mathrm{g}\right.$ TPF $\mathrm{g}^{-1}$ for $\left.24 \mathrm{~h}\right)$ \\
\hline SW1 & $5.80^{\mathrm{b}}$ & $390^{\mathrm{e}}$ & $113.00^{\mathrm{b}}$ \\
\hline SW2 & $5.63^{b}$ & $485^{\mathrm{bc}}$ & $66.50^{c}$ \\
\hline SW3 & $4.87^{\mathrm{c}}$ & $563^{\mathrm{d}}$ & $62.26^{\mathrm{c}}$ \\
\hline SW4 & $4.59^{\mathrm{d}}$ & $579^{\mathrm{c}}$ & $54.00^{\mathrm{d}}$ \\
\hline SW5 & $3.88^{\mathrm{e}}$ & $592^{\mathrm{b}}$ & $51.00^{\mathrm{d}}$ \\
\hline Ref. & $10.86^{\mathrm{a}}$ & $644^{\mathrm{a}}$ & $159.56^{\mathrm{a}}$ \\
\hline
\end{tabular}




\section{Conclusion}

Long-term irrigation with sewage wastewater could be accumulated in soils causing environmental pollution. The soil pollutants could easily be absorbed by the crops. Subsequently, they enter the human body through food chain and thus could cause health problems. People in sewage irrigation area are higher incidence of diarrhea and digestive system cancer.

The results of this study suggest that the sewage wastewater has a significant effect on the metal concentrations in the shoots of wheat, faba bean and noion, highlighting specifically $\mathrm{Cd}$ and $\mathrm{Pb}$ concentrations that are permissible for in human, or animal diets. Data also shows that the sewage wastewater has a significant effect on the quantity of common and functional microorganisms in the rhizosphere, but the magnitude of the microbial population is dependent on the crop type. The great differences of microbial quantities and species in plant rhizosphere could also be affected by the soil type and concentration of pollutants.

Acknowledgement : Professor Galal Elgharably provided guidance and Science and Technology Development Fund (STDF) sponsored the study through the project 2153 "Heavy Metals Pollution and Remediation in Soils of Assiut, Egypt".

\section{References}

Abdala, M. and Chmtelnicka, J. (1990) New aspects on the distribution and metabolism of essential trace elements after dietary exposure to toxic metals. Biot. Trace Elements Res. 23, 25-53.

Adhikari, T., Manna, M.C., Singh M.V. and Warjari, R.H. (2004) Bioremediation measure to minimize heavy metals accumulation in soils and crops irrigated with city effluent food. Agric. Environ. 2, 266-270.

Chander K. and Brookes, P.C. (1991) Effects of heavy metals from past applications of sewage sludge on microbial biomass and organic matter accumulation in a sandy loam and silty loam UK soil. Soil Biol. Biochem. 23, 927-932.

Codex Alimentarious Commission (FAO, WHO) (2001) Food additives and contaminations. Joint FAO/WHO Food Standards Program 2001: Alinorm 01/12A: 1289. (C.F. Am. Eur. J. Agric. Environ. Sci. 4, 86-92, 2008).

Coutate, T.P. (1992) Food: The chemistry of its components. $2^{\text {nd }}$ Edn. Cambridge Royal Soc. of Chems. pp. 265.

De-lan, X.U., Cui-ying, Z., Shu-ming, Q. Xu, M. and Ming-xia, G. (2012) Characterization of microorganisms in the soils with sewage irrigations. African $J$. Microbiol. Research, 6, 7168-7175.

Egypt. J. Soil Sci. 56, No. 4 (2016) 
Elgharably, A., Abdel Mageed, A. and Elgharably G. (2014) Status of heavy metals in soils of Assiut as affected by the long-term use of sewage water in crop irrigation: case study. Egyptian J. Soil Sci. (In press).

Elgharably, A. and Allam, N. (2014) Effect of arbuscular mycorrhiza on growth and metal uptake of basil and mint plants in wastewater irrigated soil. Egyptian J. Soil Sci. (In press).

Fazeli, M.S. (1998) Enrichment of heavy metal in paddy crops irrigated by paper mill effluents near Nanjanud. Mysore. District. Karnatuke. India Environ. Geo. 34: 42-54.

Feign, A., Ravina, I. and Shalhevet, J. (1991) Irrigation with treated sewage effluents: management for environmental protection. Springer, Berlin, 224 pp.

Feng, S.Y., Qi, Z.M. and Huang, G.H. (2003) Effects of fresh water and sewage irrigation on growth of winter wheat. J. Irrig. Drain. 22, 11-14.

Fliessbach, A., Martens, R. and Reber, H. (1994) Soil microbial biomass and microbial activity in soils treated with heavy metal contaminated sewage sludge. Soil Biol. Biochem. 26,1201-1205.

Goyal, S., Chander, K. and Kapoor, K. (1995) Effect of distillery wastewater application on soil microbiological properties and plant growth. Environ. Ecol. 13, 89-93.

Han, L.B., Zhou, L.B., Gan, Y.P. and Xie, X.M. (2006) Effects of reclaimed water irrigation on soil microorganism of turf. J. Beijing For. Univ. 28, 73-77.

Huang, C.G. and Wang, X. (2009) China's Farmland Sewage Irrigation Development and Its Impact on Crop Research. J. Anhui Agric. Sci. 37, 10692-10693.

Jenkinson, D.S. and Ladd J.N. (1981) Microbial biomass in soil, measurement and turn over. In: Paul EA, Ladd JN (eds) Soil biochemistry, vol 5 Marcel Dekker, New York, pp: $415-471$.

Kandeler, E., Kampichler, C. and Horak, O. (1996) Influence of heavy metals on the functional diversity of soil microbial communities. Biol. Fert. Soils 23, 299-306.

Kawatra, B.I. and Bakhetia, P. (2008) Consumption of heavy metals and minerals by adult women through food in sewage and tube well irrigated area around Ludhiana city (Punjab, India). J. Human Ecol. 23, 351-354.

Klein, D.A., Loh, T.C. and Goulding, R.L. (1971) A rapid procedure to evaluate dehydrogenase activity of soil low in organic matter. Soil Biol. Biochem. 3, 385-387.

Kumar, P.B., Dushenkov, A. N., Motto, H. and Reskin, I. (1995) Phytoextraction the use of plants to remove heavy metals from soils. Environ. Sci. Tech. 29, 1232-1238.

Li, F.D., Yu, Z.N. and He, S.J. (1996) Agricultural microbiology experiment technology. Beijing: China Agriculture Press. 
Li, H., Chen, G.X., Yang, T. and Zhang, C.G. (2005) Impacts of petroleum-containing water irrigation on microbial population and enzyme activities in paddy soil of Shenfu irrigation area. Chin. J. Appl. Ecol. 16, 1355-1359.

Liu, W.H., Zhao, J.Z., Ouyang, Z.Y., Sőderlund, L. and Liu, G.H. (2005) Impacts of sewage irrigation on heavy metal distribution and contamination in Beijing. Chin. Environ. Int. 31, 805-812.

Masto, R.S., Chhonkar, P.K., Singh, D. and Patra, A.K. (2009) Changes in soil quality indicators under long-term sewage irrigation in a sub-tropical environment. Environ. Geo. 56, 1237-1243.

Okoronkwo, I.J. and Onwuchekwa, E.C. (2005) Risk and health implications of polluted soils for crop production. African J. Biotech. 4, 1521-1524.

Rattan, R.K., Datta, S.P., Chhonkar, P.K., Suribabu, K. and Singh, A.K. (2005) Long-term impact of irrigation with sewage effluents on heavy metal content in soils, crops and groundwater: a case study. Agric. Ecosys. Environ. 109, 310-322.

Saber, M.S.M. (1986) Prolonged effect of land disposal of human wastes on soil conditions. Water Sci. Technol. 18, 371-374.

Shang, R., Li, G.D., Qu, Y.B., Liu, K. and Zhang, W.Z. (2007) Influence of brewery water irrigation on soil microflora. J. Anhui Agric. Sci. 35, 8586-8588.

Shariati, M. and Farshi, S. (1997) Heavy metal accumulation South Tehran vegetable Crops. J. Soil Water 5, 3.

Sharma, A.K. (2006) Biofertilizers for Sustainable Agriculture. Agrobios, India, pp, 407.

Smith, C.J., Hopmans, P. and Cook, F. J. (1996) Accumulation of $\mathrm{Cr}, \mathrm{Pb}, \mathrm{Cu}, \mathrm{Ni}, \mathrm{Zn}$ and $\mathrm{Cd}$ in soil following irrigation with untreated urban effluents. Aust. Environ. Poll. 94, 317-323.

StatSoft (1995) Statistica for Windows (Computer Program manual). StatSoft, Inc., Tulsa, OK.

Umbrert, W.W., Burris, R.H. and Stauffer, J.F. (1972) Manometric techniaues. A manual describing methods applicable to the study of tissue metabolism. 5th edn. Burger Pub. Co, Minneapolis.

Valsecchi, G., Gigliotti, C. and Farini, A. (1995) Microbial biomass, activity, and organic matter accumulation in soils contaminated with heavy metals. Biol. Fert. Soils 20, 253-259.

Xie, Z.P. and Ma, G.T. (2001) A study of microbiota in irrigated area aroud Zhangye paper mill. Environ. Monit. Chin. 17, 42-44.

Yadav, R.K., Goyal, B., Sharma, R.K., Dubey, S.K. and Minhas, P.S. (2002) Postirrigation impact of domestic sewage effluent on composition of soils, crops and ground water-acase study. Environ. Int. 28, 481-486.

Egypt. J. Soil Sci. 56, No. 4 (2016) 
Yang, H.X. (2002) Study on the influence of wastewater irrigation to crops. Agroenviron. Dev. 4, 18-19.

Yuan, Y.W., Zhang, W. and Ma, W. (2003) Effect of sewage irrigation on different microbial groups in soils. Water Sav. Irrig. 6, 15-17.

Zhang, J. and Wang, Y.C. (2009) Influence of irrigation with reclaimed water on soil peculiarity and microbes quantity of plant rhizosphere. Water Sav. Irrig. 3, 5-8.

Zhang, J., Zhang, H.W., Cong, F., Zhang, H. Q., Li, X.Y., Su, Z.C. and Zhang, C.G. (2007) Effects of long-term PAHs-containing wastewater irrigation on low land rice soil enzyme activities and microbia l populations. Chin. J. Ecol. 26, 1193-1198.

Wierzhicka, M. (1995) How lead loses its toxicity to plants. Acta. Soc. Bot. 64, 81-90.

Received 1/11/2015; accepted 16/12/2015) 


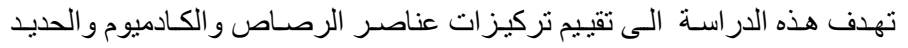

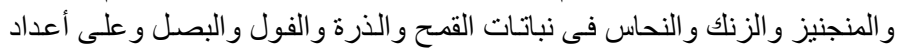

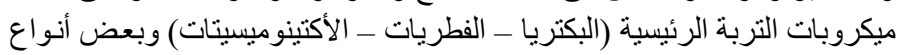

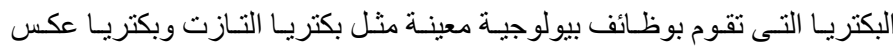

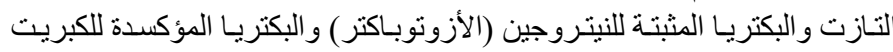

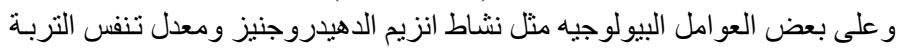

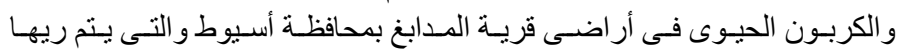
باستخدام مياه الصرف الصوى فحى منذ ما يقرب من 40 عام.

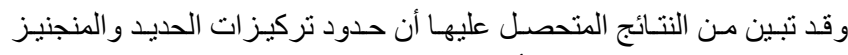

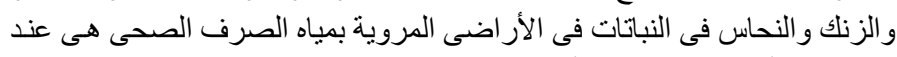

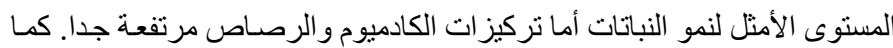

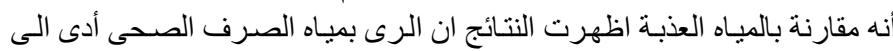

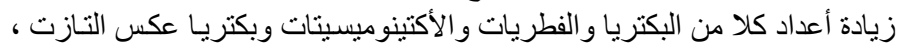

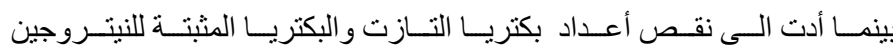

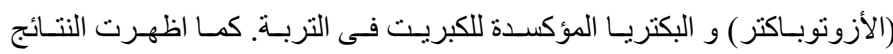

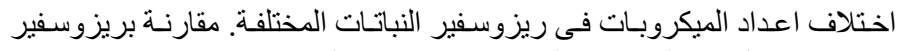

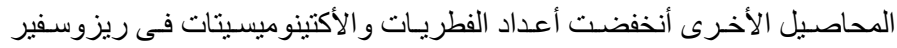

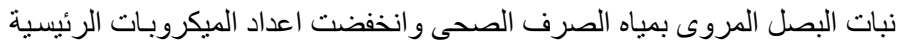

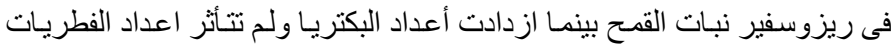

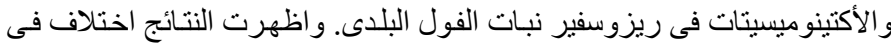

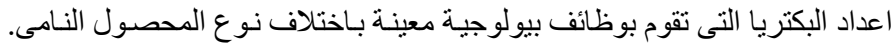

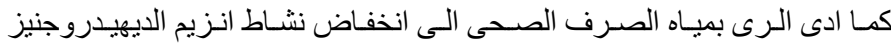

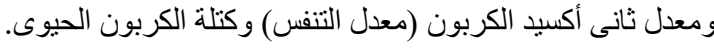

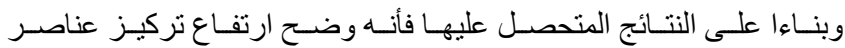

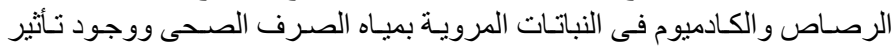

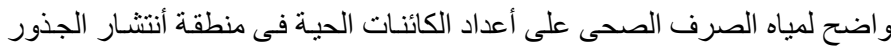
ولكن هذا العدد يتوقف على نوع النبات النامى. 